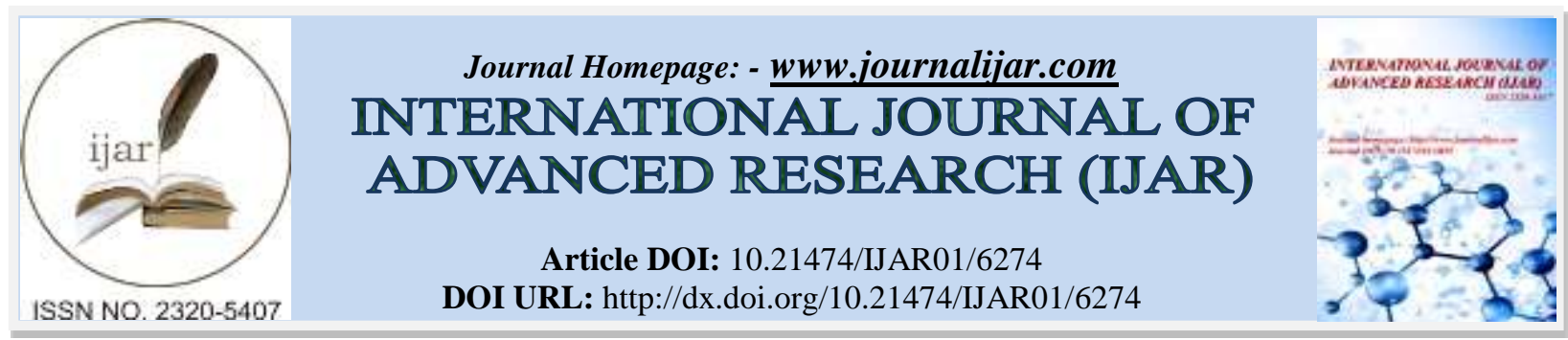

RESEARCH ARTICLE

\title{
SEVEN NEW ADDITIONS TO THE MARCHANTIOPHYTA (LIVERWORTS) BRYOFLORA OF MANIPUR, INDIA.
}

\section{Naorem Premita Devi ${ }^{1}$, S. D. Yumkham ${ }^{1}$, R. Nongmaithem ${ }^{2}$ and P. K. Singh ${ }^{1}$.}

1. Ethnobotany \& Plant Physiology Laboratory, Centre of Advanced Studies in Life Sciences, Manipur University, Canchipur-795 003, India.

2. Laboratory of Ethnobotany \& Medicinal Plant Conservation, Department of Ecology \& Environmental Science, Assam University, Silchar-788 011, India.

\section{Manuscript Info}

\section{Manuscript History}

Received: 10 November 2017

Final Accepted: 12 December 2017

Published: January 2018

Key words:-

Marchantiophyta, Manipur, New

addition, Thalloid.

\section{Abstract}

Seven (7) thalloid liverworts under two (2) genera belonging to two (2) families viz., Marchantia papillata Raddi subsp. grossibarba (Steph.) Bischl. and $M$. polymorpha subsp. ruderalis Bischl. \& Boisselier-Dubayle of Marchantiaceae and Riccia beyrichiana Hampe ex Lehm., $R$. cavernosa Hoffm., $R$. huebeneriana Lindenb., $R$. cruciata Kashyap and $R$. sorocarpa Bisch. of Ricciaceae are recorded for the first time from Manipur. Correct nomenclature, taxonomic description, habitat, distribution and photographs are provided for each species.

Copy Right, IJAR, 2018,. All rights reserved.

\section{Introduction:-}

The Bryophytes consist of tiny poikilohydric haploid dominant (n) non-tracheophyte cryptogams which have three divisions, namely, Marchantiophyta (Hepaticae or Liverworts), Bryophyta (Mosses) and Anthocerotophyta (Hornworts). More than 3000 bryophyte species have been described, thus representing the most diverse plant group after the angiosperms and it is also accepted as the oldest living land plants (Mishler \& Churchill 1984; Shaw \& Ranzaglia 2004; Ranzaglia et al. 2007). Majority are found cosmopolitan on terrestrial ecosystem in shaded humid microenvironment, wetland, and mountain ecosystems and a few on aquatic ecosystem forming an essential component of global biodiversity (Hällingback \& Hotgetts 2000).

The liverworts have two varied morphological forms-Foliose and Thallose. In foliose, the plants are differentiated into stem with two or three rows of leaves while in thalloids, the plants possess dorsal air-pores, ventral scales, pegged rhizoids, photosynthetic and storage zones. From the phylogenetic viewpoint, they are considered as the first land plants on earth with fascinating role in pollution monitoring, plant succession, microhabitation of unicellular eukaryotes, water retention, nutrient cycling and global carbon budget serving an indicator of climate change (Gignac 2001; Azeulo et al. 2011, Glime 2007). Inspite of having great ecological role, this plant group have been paid very less attention worldwide because of its miniature size, difficult taxonomy, degrading habitat, less economic importance and easily non-recognizable. However, investigations on their ethnic uses and application in herbal medicine, agriculture, aquarium and horticultural purposes have been carried out in few countries (Pant \& Tewari 1989; Kumar et al. 2000; Glime 2013).

In terms of species richness, the liverworts come after the mosses and followed by the hornworts. A total of 7274 liverwort species have been listed in the most recently published world checklist of hornworts and liverworts (Söderström et al. 2016). To assess the diversity of bryoflora, many phytogeographic regional zones have been divided throughout the world. In India, there are eight (8) bryogeographic zones viz., Western Himalays [WH], 
Eastern Himalayas [EH], Punjab and West Rajasthan [PWR], Gangetic Plains [GP], Central India [CI], Western and Eastern Ghats [WEG], Deccan Plateau [DP] and Andaman and Nicobar Islands [ANI] (Pandè 1958, Singh \& Semwal 1995). Altogether, 891 species under 134 genera in 56 families have been reported from India (Singh et al. 2016). Major contributions to the liverwort flora of India include Mitten (1861), Kashyap (1929, 1932), Pande (1936,), Chopra (1943), Pande \& Udar (1958a, 1958b), Kachroo (1969), Udar (1976), Srivastava (1964), Parihar et al. (1994), Singh (1999), Dey \& Singh (2012), Singh \& Barbhuiya (2012), Singh \& Singh (2009) and Singh et al. (2016).

The first ever collection of plants including liverworts from Manipur state was done by George Watt in 1881-82. Besides these, some collectors like Biswas \& Calder (1936), Deb (1954) and Lal (1979) reported few bryophytes from the state. However, these collectors are not bryophyte specialists and their collections were very limited. One of the most notable contributions to the state flora was made by Singh et al. (2010) and listed 111 liverworts under 46 genera in 20 families. Apart from these, no botanical exploration and assessment by any hepaticologists regarding the liverwort flora of Manipur has been made so far. During the present investigation, seven (7) interesting taxa which are not recorded in the earlier studies were collected from the study site.

\section{Materials and Methods:-}

Study site: Manipur, a Northeastern state of India, lies between (23⒌') N latitudes and (92 $\left.59^{\circ}-94^{\circ} 46^{\prime}\right)$ E longitudes and covers a total geographical area of $22,327 \mathrm{~km}^{2}$. The altitudinal variation ranges between $700-3,600$ meters above the mean sea level (mmsl). It shares national boundary with Nagaland, Mizoram and Assam to the North, South and West respectively while bordered by the international boundary of Burma to the East. The state is blessed with a unique topography of having a small lacustrine oval shaped alluvial valley encircled by ninety percent tract of hilly terrains that belong to the alpine system of the young fold mountains of Himalaya. It has nine political districts viz., Churachandpur, Ukhrul, Tamenglong, Chandel, Senapati, Imphal West, Imphal East, Thoubal and Bishnupur. The later four districts belong to the valley. The southwest monsoon is the primary source of determining the rainfall and climatic patterns throughout the state. It receives an average annual rainfall of $1600-3430 \mathrm{~mm}$ and is characterized by pleasant sub-tropical monsoon type of climate with temperature ranging from sub-zero to $36^{\circ} \mathrm{C}$. Seventy percent of the rainfall is restricted to the hilly areas. Considering the topography, physiognomy and climatic conditions, Manipur comes under the EH Bryo-geographic zone of India which is also a global biodiversity hotspot.

Data collection: Samples were collected from the valley region of the study site during repeated field surveys conducted from June 2015 to June 2017. Photographs were taken in their natural habitat. A small knife and a spatula were used to peel off the specimens. The specimens were carefully observed and examined while fresh. Recordkeeping, making herbarium packets and preservation was done by using the simple methodology of Vanderpoorten et al. (2010). Species were identified by consulting various relevant literature and publications (Srivastava 1964; Lal \& Parihar 1979; Udar \& Jain 1984; Bischler-Causse 1989; Sinha et al. 1990; Singh \& Singh 2009; Singh et al. 2010; Singh \& Singh 2013; Singh 2014). Classification by Crandall-Stotler et al. (2009) is followed for the present study. Microphotographs were taken by using Phase-Contrast Microscope MOTIC BA210. The herbarium packets as well as wet specimens of all the collected taxa were deposited in the Manipur University Museum of Plants (MUMP), Department of Life Sciences, Manipur University, Canchipur.

\section{Enumeration:-}

Marchantia papillata Raddi subsp. grossibarba (Steph.) Bischl. Cryptog. Bryol. Lichenol. 10:78. 1989 \& Bryophyt. Biblioth. 38: 210. 1989. [Plate-I, a-c]

Plants thick, light green-dark green, dichotomous repeated, profusely branching, air-pores visible; Thallus 20-50 mm long, 3-5 mm wide, dorsal dark median band, margin entire, apex notch; Ventral scales 4 rows, median two rows appendiculate, appendages ovate-subrotund and toothed with 1-2 uniseriate cells towards apex, brownish to reddish colour; Laminar scales slightly ligulate; Rhizoids pegged and smooth, hyaline; Air-pores simple, small with 5-8 superimposed concentric rings, inner pore quadrate bounded by 4 cells; Gemma cup fringed on the margin; Gemmae discoid, biconvex; Dioecious; Male receptacles stalked, hemispherical disc with 5-8 lobed, stalk 10-15 mm long; Female receptacles stalked, discoid with 6-9 lobed, stalk 20-30 mm long; Capsules yellow, ovate (1×0.7) $\mathrm{mm}$; Spores brown colour, walnut shape, elaters long, bispiral. 
Habitat:- Terricolous and saxicolous.

Fertile period:- May-July.

Status in Manipur:- Very common.

\section{Distribution:-}

India:-

Himachal Pradesh, Kashmir [WH] Punjab [PWR]; Arunachal Pradesh, Assam, Meghalaya, Nagaland, Sikkim, West Bengal, Manipur [EH]; Madhya Pradesh [CI]; Tamil Nadu [WEG]; Afghanistan, Pakistan, Nepal, Bhutan, China, Bangladesh, Myanmar, Sri Lanka, Thailand.

\section{Exsiccatae:-}

INDIA: Manipur, Imphal East, Singjamei, $732 \mathrm{~m}, 2^{\circ} 82^{\prime} 75^{\prime \prime} \mathrm{N} \& 93^{\circ} 87^{\prime} 95^{\prime \prime} \mathrm{E}$, on moist exposed area at the interface between soil and cemented wall, 07.05.2016, N. P. Devi, 003406 (MUMP).

Marchantia polymorpha subsp. Ruderalis:-

Bischl. \& Boisselier-Dubayle in J. Bryol. 16:364, 1991. [Plate-I, d-g]

Plants thick, dark green, dichotomous repeated, air-pores inconspicuous but visible, rosette while young; Thallus 30-60 mm long, 7-12 mm wide, dorsal discontinuous dark median band, margin crenulate, apex notch; Ventral scales 6 rows, median scales large, appendiculate, appendages subrotund and toothed, purplish to reddish colour; Laminar scales ligulate; Rhizoids pegged and smooth, hyaline; Air-pores simple, small with 5-7 superimposed concentric rings, inner pore quadrate-cruciate bounded by 4-6 cells; Gemma cup lobed on the margin; Gemmae discoid, biconvex; Dioecious; Male receptacles stalked, flat disc with shallow 5-10 lobed, stalk 15-20 mm long; Female receptacles stalked, discoid with deep 9-11 slender lobes, stalk 15-20 mm long; Capsules yellow, ovate $(1.5 \times 1) \mathrm{mm}$; Spores brown colour, no elaters.

Habitat:- Terricolous \& saxicolous.

Fertile period:- April-June.

Status in Manipur:- Uncommon.

\section{Distribution:-}

INDIA: Himachal Pradesh, Jammu and Kashmir, Uttarakhand [WH]; West Bengal (Darjeeling), Sikkim, Assam, Meghalaya, Manipur [EH]; Punjab, Rajasthan [PWR]; Uttar Pradesh [GP]; Tamil Nadu [WEG]; Pakistan, Afghanistan, Nepal, Bhutan, China, sri Lanka, Myanmar, Japan, Korea, Vietnam, Turkey, Iran, Iraq, Israel, Indonesia, Malaysia, Philippines, Melanesia, New Zealand, Australia, Europe, North \& South America.

\section{Exsiccatae:-}

INDIA: Manipur, Imphal West, Thumbuthong, 726m, 244ㄴ'22" N \& 93³5'78" E, on very moist exposed thick soil near river bank, 10.04.2016, N. P. Devi, 003405 (MUMP).

Riccia beyrichiana Hampe ex Lehm., Nov. strip. Pug. 7:1. 1838. [Plate-I, h; PlateII, a-b]

Plants glaucous green, rosette diameter upto $3 \mathrm{~cm}$, dichotomous 2-4 times furcate; Thallus 5-10 mm long, 2-3 mm wide, apex obtuse or rounded, lobes linear, margin swollen, entire; Dorsal median groove deep and narrow at anterior region, shallow and broad in middle, absent in posterior region; Ventral scales hyaline or violet, inconspicuous; Rhizoids pegged and smooth, hyaline; Cross section of thallus differentiated into upper compact photosynthetic zone with pyriform-rotundate epidermal cells and lower parenchymatous, storage cells arranged in vertically oriented rows with canal-like air chambers between them (Euriccia-type), anterior concavo-convex, posterior plano-convex; Monoecious; Capsules protruded on dorsal surface; Spores brown-dark brown, tetrahedral, globose, 80-93 $\mu \mathrm{m}$, distal surface imperfectly reticulate, with 7-9 reticulations across, margin crenate.

Habitat:- Terricolous.

Fertile period:- June-August and December-March.

Status in Manipur:- Common.

Distribution:- INDIA: Himachal Pradesh [WH]; Meghalaya, Manipur [EH]; Pakistan, Macronesia, Europe, North Africa, North America. 
Exsiccatae:- INDIA: Manipur, Imphal East, Singjamei, $732 \mathrm{~m}, 24^{\circ} 82^{\prime} 80^{\prime \prime} \mathrm{N} \& 93^{\circ} 87^{\prime} 90^{\prime \prime}$ E, on moist thick exposed alluvial clayed soil, 20.06.2016, N. P. Devi, 003409 (MUMP).

Riccia cavernosa Hoffm. Deutschl. Fl. 2 (Cryptog.): 95. "1796" 1796. emend. Raddi, Opusc. Sci. (Bologna) 2: 351. 1818. Deutschl. Fl., Theil 2 (Hoffm.): 95, 1795 [1796] (Hoffmann 1795). [Plate-I, i-j; Plate-II, c-d]

Plants glaucous green-reddish green, spongy, rosette diameter 1.5-2 cm, dichotomous crowded and overlapping; Thallus 5-9 mm long, 2-4 mm broad; Dorsal groove prominent only at apex; Ventral scales absent; Epidermal cells globose; Rhizoids pegged and smooth, hyaline; Cross section of thallus differentiated into upper photosynthetic zone with large air chambers, pores and lower compact, parenchymatous storage zone (Ricciella-type); Monoecious; Capsules slightly protruding on ventral side, 1-3 rows; Spores brown, globose to subglobose, 70-87 $\mu \mathrm{m}$, anisopolar, distal surface have incomplete reticulations of lamellae incrusted with granules, reticulations widely spaced and occasionally form continuous ridge along the periphery at inner side of wing, proximal surface have prominent triradiate mark, each faces bear granules forming simple or branching and anastomosing ridges which occasionally form complete reticulum, wing broad, margin crenate.

Habitat:- Terricolous.

Fertile period:- December-February.

Status in Manipur:- Uncommon.

Distribution:- INDIA: Himachal Pradesh [WH]; West Bengal Hills [EH]; Uttar Pradesh [GP]; Madhya Pradesh [CI]; Rajasthan [PWR]; Pakistan, Russia, North America, Europe, Australia.

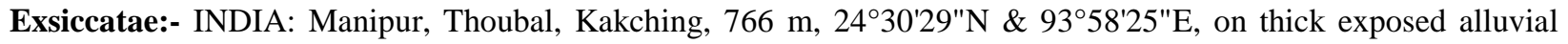
clayed soil of river bank, 05.12.2016, N. P. Devi, 003429 (MUMP).

Riccia cruciata Kashyap, J. Bombay Nat. Hist. Soc. 24: 349. 1916. [Plate-I, k; Plate-II, e-f]

Plants pale green-yellowish green, shiny, little spongy, rosette diameter $12-15 \mathrm{~mm}$, dichotomous $1-2$ furcate; Thallus obovate, cruciate, 6-7 mm long, 5-6 mm broad; Dorsal groove shallow and prominent towards apex; Ventral scales inconspicuous; Epidermal cells globose; Rhizoids pegged and smooth, hyaline; Cross section of the thallus differentiated into upper photosynthetic zone with large air chambers, pores and lower compact, parenchymatous storage zone; Monoecious. Capsules prominent on the ventral surface, 1-2 rows; Spores golden brown, globose-triangular, 59-72 $\mu \mathrm{m}$, anisopolar, distal surface with 4-5 reticulations across diameter, each reticulum complete with low short papilla at centre, partition wall of the reticulum crenulate or with minute puncti, proximal surface with prominent triradiate mark, each face with 7-12 angular reticulations with no central papilla, wing broad, margin slightly undulate-crenate.

Habitat:- Terricolous.

Fertile period:- January-March.

Status in Manipur:- Uncommon.

Distribution:- INDIA: Kerala, Maharastra [WEG]; Nagaland, West Bengal, Manipur [EH], Uttar Pradesh [GP]; Punjab [PWR]; Uttaranchal [WH]; Indonesia, Pakistan.

Exsiccatae:- INDIA: Manipur, Thoubal, Keirak, $766 \mathrm{~m}, 24^{\circ} 30^{\prime} 50^{\prime \prime} \mathrm{N} \& 93^{\circ} 57^{\prime} 46^{\prime \prime} \mathrm{E}$, on thick exposed alluvial clayed soil of river bank, 05.12.2016, N. P. Devi, 003433 (MUMP).

Riccia huebeneriana Lindenb., Nova Acta Phys.-Med. Acad. Caes. Leop.-Carol. Nat. Cur. 18: 504. 1836. [Plate-I, I; Plate-II, g-h]

Plants light green, semi-rosette not compact, dichotomous 2-3 furcate; Thallus narrow, 8-10 mm long, 1-1.5 mm wide, linear, ribbon-shaped, apex rounded, margin entire; Dorsal median groove continuous, shallow at apex; Ventral scales inconspicuous; Epidermal cells elongated pentagonal to hexagonal; Rhizoids pegged and smooth, hyaline; Cross section of thallus differentiated into upper photosynthetic zone with large air chambers and pores and lower compact, parenchymatous highly reduced storage zone (Ricciella-type); Monoecious; Capsules prominent on ventral surface right below the dichotomous point, arranged in single row; Spores golden yellow, subglobose to 
triangular, 50-75 $\mu \mathrm{m}$, anisopolar, distal surface with 6-8 reticulations across diameter, proximal surface show prominent triradiate mark with incomplete reticulations, wing broad, margin entire to crenate.

Habitat:- Terricolous.

Fruiting period:- July-August and November-February.

Status:- Very common.

Distribution:- INDIA: Uttar Pradesh [WH]; Assam, Sikkim, West Bengal [EH]; Chattisgarh, Madhya Pradesh [CI]; Karnataka, Kerala [WEG]; China, Japan, Korea, Europe, Africa, North America.

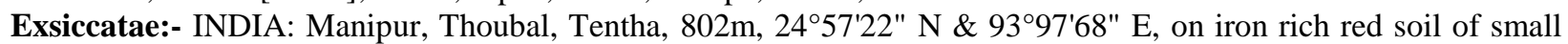
hillocks, 02.07.2016, N. P. Devi, 003410 (MUMP).

Riccia sorocarpa Bisch., Nova Acta Phys.-Med. Acad. Caes. Leop.-Carol. Nat. Cur. 17: 1053. 1835. [Plate-I, m; Plate-II, i-j]

Plants glaucous green, white margin in matured plants, dichotomous 2-3 furcate, gregarious branching; Thallus 5-7 $\mathrm{mm}$ long, $2 \mathrm{~mm}$ wide, oblong-ovate, apex subacute, margin entire; sulcus very prominent upto the middle; Ventral scales small and colourless, along margin; Epidermal cells oval, soon invisible, subepidermal cells persisting; Rhizoids pegged and smooth, hyaline; Cross section of thallus differentiated into upper compact photosynthetic zone (Euriccia-type); Monoecious; Capsules prominent on the ventral side, arranged in 2-3 rows; Spores black to dark brown, globose to subglobose, $62-83 \mu \mathrm{m}$, anisopolar, distal surface with 8-11 reticulations, proximal surface have inconspicuous triradiate mark with complete to incomplete reticulations; Wing broad, margin crenulate to serrulate.

Habitat:- Terricolous.

Fruiting period:- November-February.

Status in Manipur:- Very Common.

Distribution:- Himachal Pradesh, Uttarakhand [WH]; West Bengal Hills, Manipur [EH]; Tamil Nadu [WEG]; Japan, China, Africa, Europe, North America.

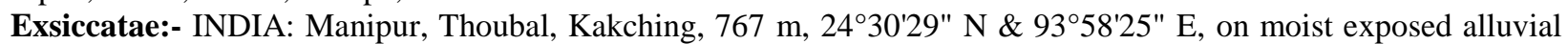
clayed soil, 27.11.2016, N. P. Devi, 003417 (MUMP).

Notes: Most of the Riccia spp. occured singly on the moist exposed thick alluvial clayed soil at the river bank with no other associated plants. $R$. huebeneriana and $R$. sorocarpa sometimes clustered together as mixed population and are also found in shaded iron rich red soil of small hillocks at a higher altitude as compared to other Riccia spp. 


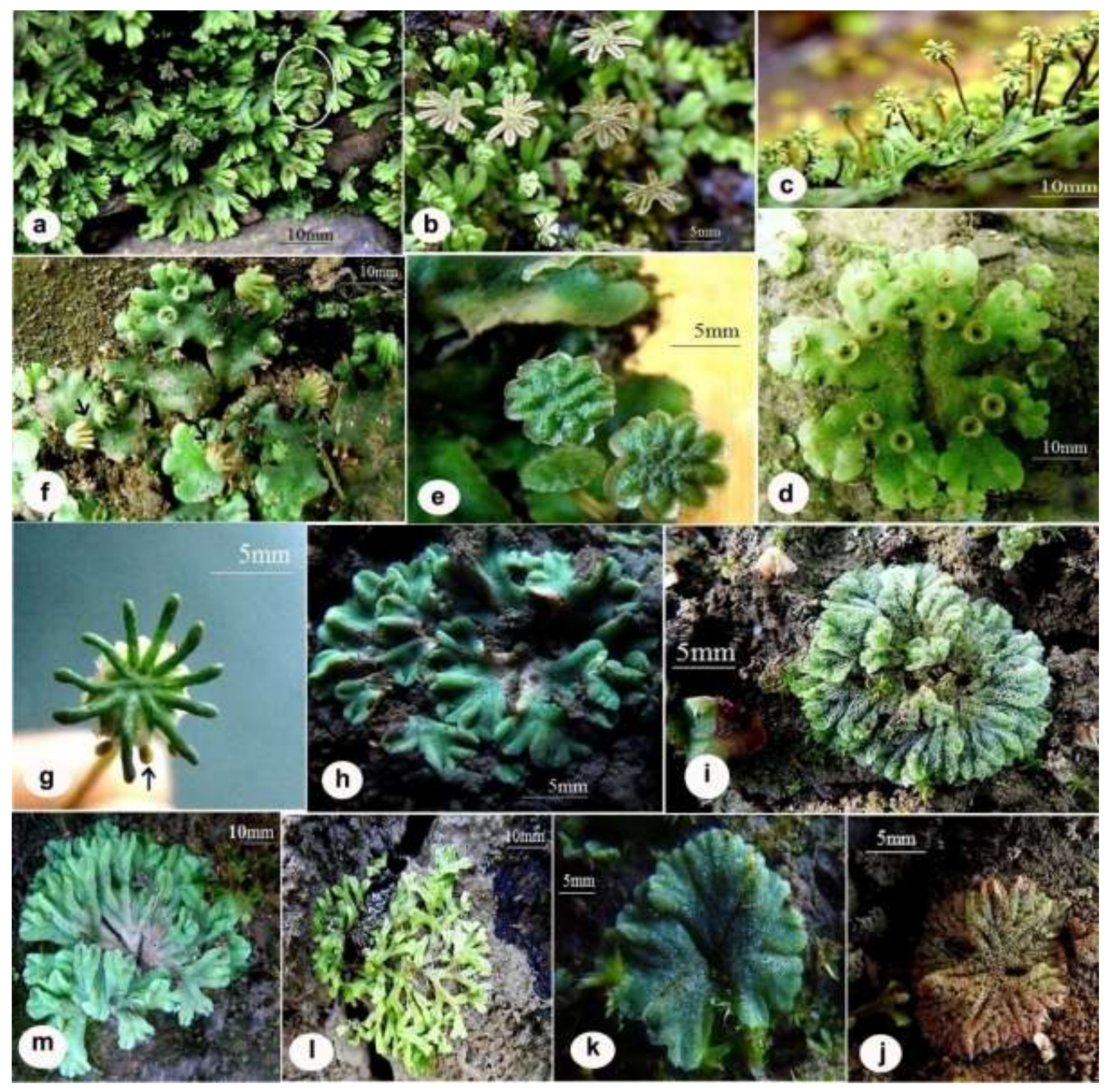

Plate-I:- Habit. a-c. Marchantia papillata subsp. grossibarba. a. Gametophyte bearing gemma cups (encircled); b. Male plants; c. Female plants with dehiscing capsule. d-g. M. polymorpha subsp. ruderalis. d. Gametophyte bearing gemma cups; e. Male receptacle; f. Female plants showing female receptacle (arrowheads); g. Female receptacle with sporophyte capsules (arrowhead) h. Riccia beyrichiana Hampe ex Lehm. i-j. R. cavernosa Hoffm. i. Glaucous green thallus j. Reddish green thallus. k. $R$. cruciata Kashyap. I. R. huebeneriana Lindenb. m. $R$. sorocarpa Bisch. 


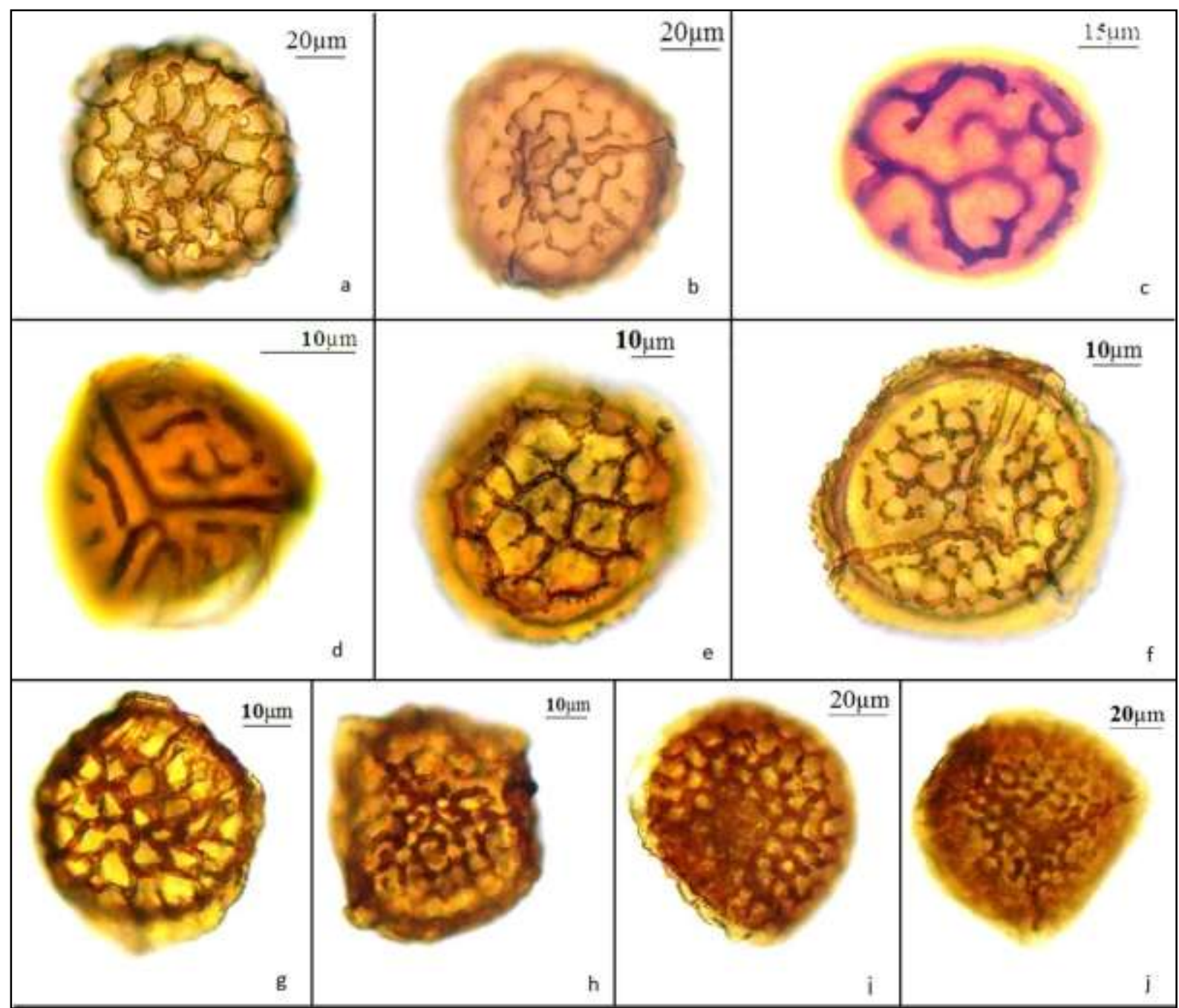

Plate-II:- Spores of Riccia sp. a-b. Riccia beyrichiana Hampe ex Lehm. a. Distal surface; b. Proximal surface. cd. $\boldsymbol{R}$. cavernosa Hoffm. c. Distal surface; d. proximal surface. e-f . R. cruciata Kashyap. e. Distal surface f. Proximal surface; g-h. $R$. huebeneriana Lindenb. g. Distal surface h. Proximal surface; $\mathbf{i}-\mathbf{j}$. Riccia sorocarpa Bisch. i. Distal surface j. Proximal surface.

\section{Acknowledgements:-}

The authors are thankful to Dr. A. A. Mao, Scientist-F and Head of Office, Botanical Survey of India, Eastern Regional Centre, Shillong for giving permission to consult herbarium specimens. Special thanks to Dr. S. K. Singh, Scientist-D of the same institute for his co-operation and assistance in identification and authentification.

\section{Literature Cited:-}

1. Azeulo, A.G.; Sariana, L.G. \& Pabulan, M.P. 2011. Some Medicinal Bryophytes: their Ethnobotanical Uses and Morphology. Asian J. of Biodiversity 2: 49-80.

2. Bischler-Causse, H. 1989. Marchantia L. The Asiatic and Oceanic taxa. Bryophyt. Biblioth. 38: 1-317.

3. Biswas, K. \& Calder, C.C. 1936. Handbook of Common Water and Marsh Plants of India and Burma. Health Bulletin No. 24, Malaria Bureau No. 11. Delhi.

4. Chopra, R.S. 1943. A census on Indian hepatics. J. Ind. Bot. Soc. 22: 237-259.

5. Crandall-Stotler, B.; Stotler, R.E. \& Long, D.G. 2009. Phylogeny and Classification of the Marchantiophyta. Edinburg J. of Bot. 66 (1): 155-198. Doi:10.1017/S0960428609005393.

6. Deb, D.B. 1954. On the occurrence of Riccia natans Corda from the Eastern Himalayas. Sci \& Cult. 19: 353354

7. Dey, M. \& Singh, D.K. 2012. Epiphyllous Liverworts of Eastern Himalaya. BSI, Kolkata. 
8. Gignac, L.D. 2001. Bryophytes as indicators of Climate Change. The Bryologist 104(3): 410-420.

9. Glime, J.M. 2007. Economic and Ethnic uses of bryophytes. Flora of North America 27: 14-18.

10. Glime, J.M. 2013. Meet the Bryophytes. Vol. 1. Ebook sponsored by Michigan Technological University and the International Association of Bryologists.

11. Hallingbäck, T. \& Hodgetts, N. 2000. Mosses, Liverworts, and Hornworts. Status Survey and Conservation Action Plan for Bryophytes. IUCN/SSC Bryophyte Specialist Group. IUCN, Gland, Switzerland and Cambridge, UK. 106pp.

12. Kachroo, P. 1969. Hepaticae of India-A taxonomic survey and census I. Floristic and taxonomic considerations. Kashmir J. Sci. 6: 39-55.

13. Kashyap, S.R. 1929. Liverworts of the Western Himalayas and the Punjab Plain I. The University of the Punjab, Lahore.

14. Kashyap, S.R. 1932. Liverworts of the Western Himalayas and the Punjab Plain II. The University of the Punjab, Lahore.

15. Kumar, K.; Singh, K.K.; Asthana, A.K. \& Nath, V. 2000. Ethnotherapeutics of Bryophyte Plagiochasma appendiculatum among the Gaddi Tribes of Kangra Valley, Himachal Pradesh, India. Pharmaceutical Biology 38(5): 353-356.

16. Lal, J. \& Parihar, N.S. 1979. Contributions to the bryoflora of Central Indian Zone 1-Liverworts. J. Ind. Bot. Soc. 58: 110-114.

17. Lal, J. 1979. Epiphyllous bryophytes of Manipur I. Metzgeriaceae. Proc. Ind. Sci. Congress 42-43.

18. Mishler, B.D. \& Churchill, S.P. 1984. A cladistic approach to the phylogeny of the bryophytes. Brittonia 36: 406-424.

19. Mitten, W. 1861. Hepaticae Indiae Orientalis, an enumeration of the Hepaticae of East Indies. J. Proc. Linn. Soc. Bot. 5: 89-128.

20. Pande, S.K. \& Udar, R. 1958a. Genus Riccia in India II. Species of Riccia from South India with description of a new species and notes on the synonymy of some recently described ones. Proc. Nat. Inst. Sci. 24(2): 79-88.

21. Pande, S.K. \& Udar, R. 1958b. Genus Riccia in India III. Species of Riccia from the East Himalayan territory with description of a new species, R. attenuata Pande sp. nov. Proc. Natl. Inst. Sci. Ind. 25(2): 90-100.

22. Pande, S.K. 1936. Studies in Indian Liverworts: A review. J. Ind. Bot. Soc. 15: 221 - 233.

23. Pande, S.K. 1958. Some aspects of Indian Hepaticology. J. Ind. Bot. Soc. 37: 1-26.

24. Pant, G. \& Tewari, S.D. 1989. Various human uses of Bryophytes in the Kumaon Region of Northwest Himalaya. Bryologist 92(1): 120-122.

25. Parihar, N.S.; Lal, B. \& Katiyar, N. 1994. Hepatics and Anthocerotes of India - a new annotated checklist. Central Book Depot, Allahabad.

26. Ranzaglia, K.S.; Schuette, S.; Duff, R.J.; Ligrone, R.; Shaw, A.J.; Mishler, B.D. \& Duckett, J.G. 2007. Bryophyte phylogeny: advancing the molecular and morphological frontiers. Bryologist 110: 179-213.

27. Shaw, J. \& Ranzaglia, K.S. 2004. Phylogeny and diversification of bryophytes. Amer. J. Bot. 91: $1557-1581$.

28. Singh, D. \& Singh, D.K. 2013. An Appraisal of the genus Marchantia in India with a Note on Marchantia emarginata subspecies emarginata in Indian Himalayan Region. Proc. Natl. Acad. Sci., India, Sect. B Biol. Sci. 83(1): 15-26.

29. Singh, D.; Dey, M. \& Singh, D.K. 2010. A synoptic flora of Liverworts and Hornworts of Manipur. Nelumbo 52: 9-52. doi:10.20324/nelumbo/v52/2010/57702.

30. Singh, D.K. 1999. Indian Hepaticae: status and strategies. Ann. Forest. 7: 199-211.

31. Singh, D.K. and Semwal, R.C. 1995. Liverworts. In: V. Mudgal and P.K. Hajra (eds.), Bharat ki vanaspati vividhta: 225-246. BSI, Dehradun.

32. Singh, D.K.; Singh, S.K. \& Singh, D. 2016. Liverworts and Hornworts of India - an annotated checklist. BSI, Kolkata.

33. Singh, S.K.; Bag, A.K. \& Bhattacharya, S.G. 2010. Riccia (Hepaticae: Ricciaceae) of West Bengal. Taiwania 55: 99-109.

34. Singh, S.K. \& Barbhuiya, H.A. 2012. A Compendium to Marchantiophyta and Anthocerotophyta of Assam. Ind. Archive for Bryology 149: 1-30

35. Singh, S.K. \& Singh, D.K. 2009. Hepaticae and Anthocerotae of Great Himalayan National Park and its environs (HP), India. BSI, Dehradun.

36. Singh, S.K. 2014. An Appraisal of Genus Riccia in India with a Note on Diversity and Distribution of species. Int. J. of Sustainable Water and Environmental Systems 6(1): 35-43.

37. Sinha, A.B.; Singh, U.S. and Shukla, M.S. 1990. Genus Riccia (Mich.) L. of district Gorakhpur. J. Econ. Tax. Bot.14: 201-203. 
38. Söderström, L.; Hagborg, A.; Konrat, M.; Bartholomew-Began, S.; Bell, D.; Briscoe, L.; Brown E.; Cargill, D. C.; Costa, D. P.; Crandall-Stotler, B. J.; Cooper, E. D.; Dauphin, G.; Engel, J. J.; Feldberg, K.; Glenny, D.; Gradstein, S. R.; He, X.; Heinrichs, J.; Hentschel, J.; Ilkiu-Borges, A. L.; Katagiri, T.; Konstantinova N. A.; Larraín, J.; Long, D. G.; Nebel, M.; Pócs, T.; Puche, F.; Reiner-Drehwald, E; Renner, A. M.; Sass-Gyarmati, A.; Schäfer-Verwimp, A.; Moragues, J. G. S.; Stotler, R. E.; Sukkharak, P.; Thiers, B. M.; Uribe, J.; Váňa, J. and Villareal, J. C. 2016. World checklist of hornworts and liverworts. Phytokeys 59: 1-828.

39. Srivastava, K.P. 1964. Bryophytes of India I. Ricciaceae. Bulletin of the National Botanical Gardens, Lucknow. 104: $1-103$.

40. Udar, R. 1976. Bryology in India. Chronica Botanica, New Delhi.

41. Udar, R. \& Jain, A. 1984. Liverworts of Kerala-I. Marchantiales. Ind. J. of Forestry 7: 300-304.

42. Vanderpoorten, A.; Papp, B. \& Gradstein, R. 2010. Chapter 13: Sampling of Bryophytes. Vol. 8. Abc taxa, Belgium. 